\title{
Graphene-based biosensors for the detection of prostate cancer protein biomarkers: a review
}

\author{
Li Xu ${ }^{1,2}$, Yanli Wen ${ }^{1}$, Santosh Pandit ${ }^{2}$, Venkata R. S. S. Mokkapati ${ }^{2}$, Ivan Mijakovic ${ }^{2,3^{*}}$, Yan Li ${ }^{1}$, Min Ding ${ }^{1}$, \\ Shuzhen Ren', Wen Li ${ }^{1}$ and Gang Liu ${ }^{1 *}$ (D)
}

\begin{abstract}
Prostate cancer (PC) is the sixth most common cancer type in the world, which causes approximately $10 \%$ of total cancer fatalities. The detection of protein biomarkers in body fluids is the key topic for the diagnosis and prognosis of PC. Highly sensitive screening of PC is the most effective approach for reducing mortality. Thus, there are a growing number of literature that recognizes the importance of new technologies for early diagnosis of PC. Graphene is playing an important role in the biosensor field with remarkable physical, optical, electrochemical and magnetic properties. Many recent studies demonstrated the potential of graphene materials for sensitive detection of protein biomarkers. In this review, the graphene-based biosensors toward PC analysis are mainly discussed in two groups: Firstly, novel biosensor interfaces were constructed through the modification of graphene materials onto sensor surfaces. Secondly, ingenious signal amplification strategies were developed using graphene materials as catalysts or carriers. Graphene-based biosensors have exhibited remarkable performance with high sensitivities, wide detection ranges, and long-term stabilities.
\end{abstract}

Keywords: Prostate cancer, Protein biomarker, Graphene, Biosensor

\section{Introduction}

$\mathrm{PC}$ is one of the most common cancers in the world which causes a fatality of approximately $10 \%$ in all cancer patients [1-4]. PC is a type of malignant neoplasm of the prostate gland which is extremely prevalent among men of age 50 and older $[5,6]$. The established risk factors for PC include advancing age, race, positive family history of $\mathrm{PC}$ and diet $[7,8]$. Being asymptomatic, it is very difficult to detect $\mathrm{PC}$ at early stages [9]. In clinical practice, early screening and diagnosis of $\mathrm{PC}$ is the most effective approach for reducing mortality $[9,10]$. Thus, there is a growing body of literature that recognizes the

\footnotetext{
*Correspondence: ivan.mijakovic@chalmers.se; liug@simt.com.cn ${ }^{1}$ Laboratory of Biometrory, Division of Chemistry and lonizing Radiation Measurement Technology, Shanghai Institute of Measurement and Testing Technology, Shanghai 201203, People's Republic of China

2 Division of Systems and Synthetic Biology, Department of Biology and Biological Engineering, Chalmers University of Technology, 41126 Gothenburg, Sweden

Full list of author information is available at the end of the article
}

importance of new technologies for early screening and diagnosis of $\mathrm{PC}[11,12]$.

Tumor markers for early clinical screening and rapid diagnosis cover a wide range of biochemical entities, including, proteins [13, 14], nucleic acids [15-17], small metabolites $[18,19]$, cytogenetic and cytokinetic parameters [20], and entire tumor cells [21, 22] in body fluid [23]. So far, protein biomarkers are still recognized as a golden standard for PC diagnosis [24]. In the past few decades, a variety of promising biosensors have been developed based on the specific recognition of PC protein biomarkers, aiming at better performance of cancer diagnosis such as easy operation, portability, and real-time analysis [25-28]. Among them, the graphene-based biosensors have received considerable critical attention for the potential use in point-to-care (POC) testing devices, because of the unique properties of graphene such as large surface area, high electrical conductivity, excellent 
biocompatibility and convenient production/functionalization [29-31].

This review highlights recent graphene-based biosensors for PC protein biomarkers detection. As far as we know, this is the first review that focuses on specific one disease. We reviewed recent progress of graphene-based biosensors for PC protein biomarker detection. Our manuscript clearly stated the advantages and shortcomings of most of the graphene-based when facing PC diagnosis, thus, the manuscript should be valuable for the future application of graphene-based biosensors.

\section{Most commonly used protein biomarkers for PC detection}

Protein biomarkers for cancer diagnosis are usually produced by either cancer cells or other cells in response to cancer [32-34], which have been proved to be promising targets for early diagnosis, monitoring treatment response, detecting recurrence or following up prognosis of cancer [35-37]. Protein biomarkers are usually in low abundance and unstable in body fluids, and thus, the specific detection of protein biomarkers is usually affected by the crude or complex environment $[33,38]$. Thus, sensitivity, specificity, and accuracy are basic requirements to consider for protein biosensor fabrication [39-41].

Prostate-specific antigen (PSA) [42], which is also called human kallikrein 3 (hK3 or KLK3), has been widely recognized in clinical application as one of the earliest found, serological PC biomarkers [43, 44]. The PSA value above $4.0 \mathrm{ng} / \mathrm{mL}$ is usually considered as abnormal [45], thus, $4.0 \mathrm{ng} / \mathrm{mL}$ of PSA is the internationally recognized threshold value for PC occurrence [46, 47]. However, the specificity of PSA is still limited [48], because higher PSA levels can also be found in benign conditions, such as benign prostatic hyperplasia (BPH) [49-51], and PSA could be produced by normal breast and breast cancer cells [48]. These limitations indicate that PSA alone is not an appropriate surrogate marker for the diagnosis and screening of PC. Fortunately, several other protein PC biomarkers are developed.

Prostate-specific membrane antigen (PSMA) [52] is a type II transmembrane protein, and PSMA expression has been reported in benign prostatic hyperplasia and increased to higher lever in high-grade prostatic intraepithelial neoplasia and prostatic adenocarcinoma [53]. Further, stronger PSMA expression correlates to malignancy $[54,55]$. The available research results suggest the potential clinical use for PSMA in PC patients. So far, the major PSMA clinical application has been in therapeutics and imaging [56-58]. Prostate stem cell antigen [59] is another recently discovered PC biomarker [60], which is highly expressed by a large number of human prostate tumors, such as metastatic and hormone-refractory, but barely expressed in normal tissues [60-62]. Engrailed-2
(EN2) protein is found in the urine sample of prostatic cancer patients and showed a specificity of $88.2 \%$ and a sensitivity of $66 \%$ [63, 64]. Therefore, the EN2 in urine is widely recognized as a potential biomarker of PC.

\section{Properties of graphene materials in biosensor study}

Graphene is a two-dimensional (2D) nanomaterial, which plays an important role in the biosensor field [64-66]. The use of graphene in biosensing platform offers remarkable physical, optical, electrochemical and magnetic properties [67-70]. Different kinds of graphene materials are researched in biosensors including pristine graphene and functionalized graphene such as graphene oxide (GO), reduced graphene oxide (rGO), and graphene-based quantum dots (GQDs), etc. [71-74]. Pristine graphene is identified as the array of a $2 \mathrm{D}$ hexagonal lattice of $\mathrm{sp}^{2}$-bonded carbon atoms. $\mathrm{GO}$ is chemically produced by oxidation and exfoliation of graphene, causing extensive oxidative modification of the basal plane [31, 75-77]. The rGO is prepared through reductive process of $\mathrm{GO}$, for this purpose, different methods have been developed to reduce its oxygen content, including thermal, chemical, microwave, photochemical, microbial/bacterial, and photo-thermal methods [78-80]. GQDs consist of single to tens of layers of graphene with a size of a few nanometers which exhibit quantum phenomena $[81,82]$.

Development of protein biosensors based on graphene could be classified into two main groups (Fig. 1): Firstly, functioned graphene materials including $\mathrm{GO}, \mathrm{rGO}$ and GQDs [72] were assembled onto the biosensor surface [electrode, field-effect transistors (FET) channel, etc.] to construct novel biosensor interfaces for improved assembling of molecular receptors [83]. In this group, excellent biosensor performance was achieved mainly based on the increased specific surface area and the unique $\pi-\pi$ orbital interaction on the interface. Secondly, many recent studies applied graphene materials as excellent carriers for the construction of novel nanocomposites [84], and in this group, interesting biosensor signal amplification and unique catalytic/chemical activity was realized for sensitive protein biomarker analysis [85].

\section{Biosensor interfaces based on graphene}

Graphene and its derivatives are studied for the construction of novel biosensor interface [67], which is critical for interface-based biosensors including electrochemical biosensors, electrochemiluminescent (ECL) biosensors and FET biosensor [86]. Many recent studies reported that nanocomposites based on graphene showed improved capability of combining different biomolecules, with higher surface area [87] and excellent biocompatibility [88]. 

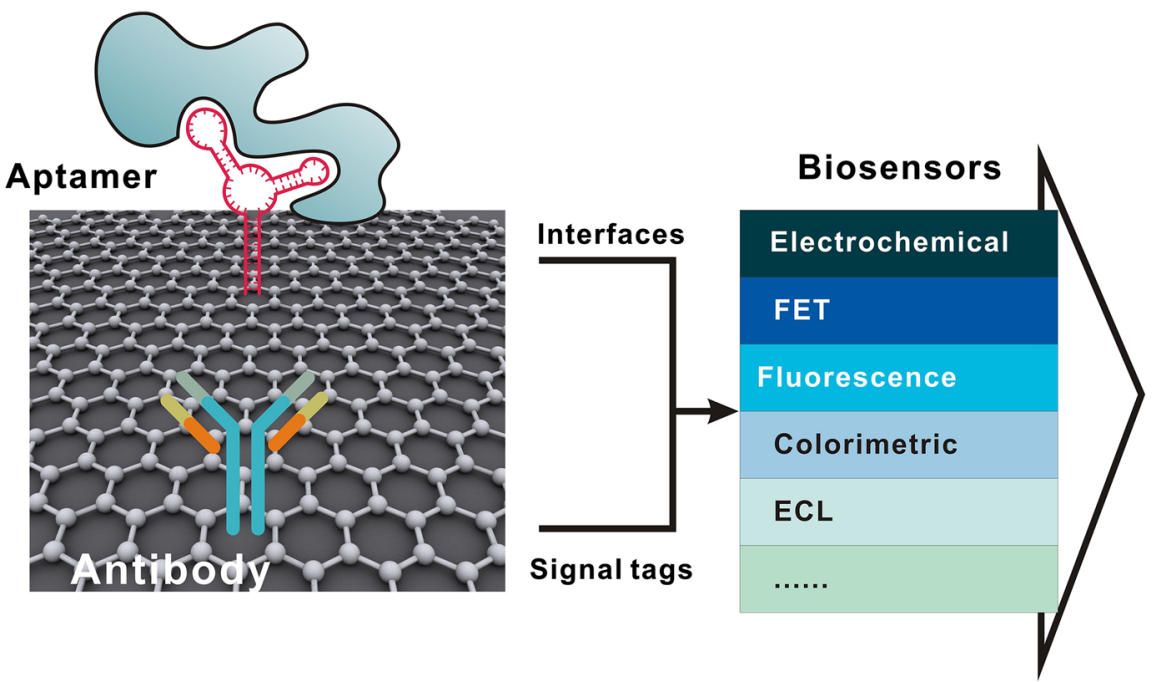

\section{Prostate \\ Cancer Protein}

Biomarkers

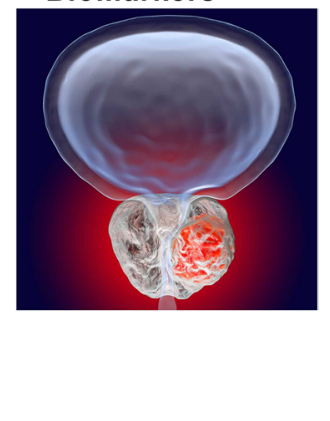

Fig. 1 For prostate cancer detection, graphene materials are applied for the construction of novel interfaces and signal tags, on different analysis platforms including electrochemical, FET, fluorescence, colorimetric, ECL biosensors, et al

\section{Construction of antibody-graphene biosensor interface}

Traditionally, antibodies are physically adsorbed onto the immune-assay surfaces, such as classic 96-well plates and colloidal gold test strips. However, one of the main obstacles is the affinity and capacity, because the hydrophobic and hydrophilic interaction is relatively weak and the orientation of the antibody molecules is random [89]. As several recent studies reported, the strong cross-linking between carboxylic acid groups on graphene materials and the amine groups of antibodies $\left(\mathrm{COOH}-\mathrm{NH}_{2}\right)$ was used for the assembling of antibody on novel biosensor interfaces $[90,91]$. In their work, the application of graphene materials increased the loading amount, orientation controllability as well as binding capability of the antibodies or antibody fragments. For example, Li et al. developed a graphene modified sensor platform with increased surface area, and then assembled antibody onto the surface through $\mathrm{COOH}-\mathrm{NH}_{2}$ combining, with the assistant of 1-ethyl-3-(3-dimethylaminopropyl) carbodiimide (EDC) and $N$-hydroxysuccinimide (NHS), and they finally achieved a low detection limit of $2 \mathrm{pg} / \mathrm{mL}$ [92].

In order to realize better-oriented assembling of antibody, Mao et al. applied chitosan as the dispersant to construct an immuno-interface on a glassy carbon electrode (Fig. 2A), which provided much more amino groups for PSA antibody bonding. They finally developed a simple, label-free electrochemical immunosensor on graphene-methylene blue composite modified electrode [93]. More recently, Jang et al. developed a novel 3D graphene-Au composite (Fig. 2B), toward increased accessible surface area for antibody combination than $2 \mathrm{D}$ graphene sheet. More importantly, the crumpled graphene could produce higher capacitances, which is crucial for the following electrochemical immunosensing [94].

A graphene-modified electrode was also reported in ECL biosensor [95] for PSA detection. More recently, Wu et al. developed an electrode surface modified with $\mathrm{Au} / \mathrm{Ag}-\mathrm{rGO}$ (Fig. 3A), and then, a large amount of aminated GQDs and carboxyl GQDs were combined onto the electrode surface. In their work, Au and Ag nanoparticles were used for the adsorption of PSA antibody, and meanwhile, GQDs were for the ECL signal amplification. Finally, they constructed a label-free PSA ECL biosensor with a detection limit as low as $0.29 \mathrm{pg} / \mathrm{mL}$ [96].

Graphene materials were also applied in FET biosensors, for the construction of $2 \mathrm{D}$ nano-FET biosensors [97-101], with unique advantages like more receptor biomolecules, low noise, and high sensitivity, compared with 1D FET biosensors [102-104]. As a successful example, Kim and coworkers [105] developed an rGO-based FET biosensor for label-free and ultrasensitive analysis of PSA/ 1 -antichymotrypsin (PSA-ACT) (Fig. 3B). The FET biosensor was produced by combining rGO onto an aminated glass surface, and then, functionalized with PSA antibody. When PSA-ACT was captured by the antibodies on FET substrate, a linear shift of the gate voltage $\left(\Delta V_{g, \text { min }}\right)$ was achieved, indicating the minimum conductivity. Finally, they successfully performed detection of PSA-ACT of femtomolar level.

\section{Construction of aptamer-graphene biosensor interface} For interface-based PC biosensors, the DNA capture probe plays a key role, which could recognize and 


\section{A Graphene}
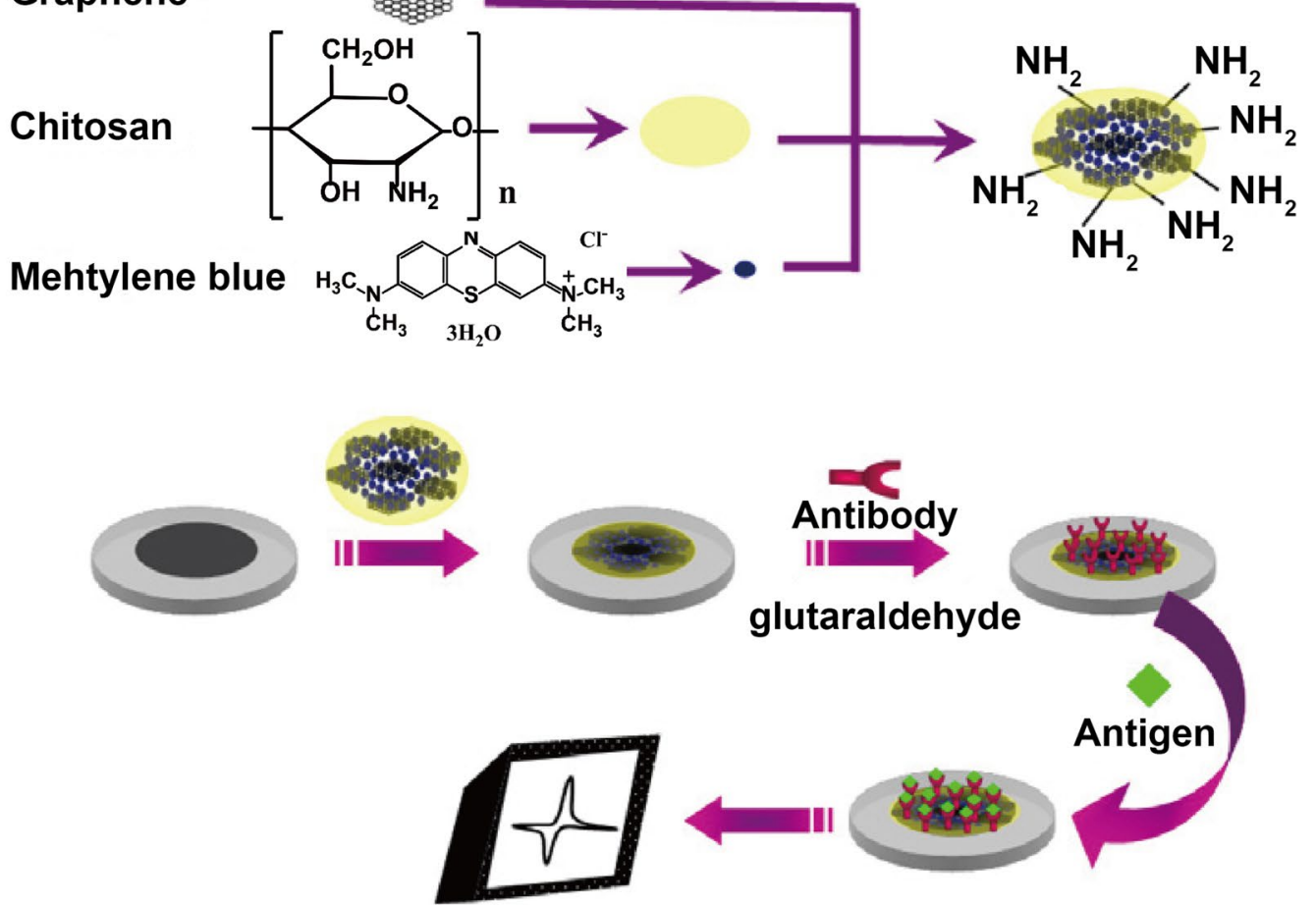

B

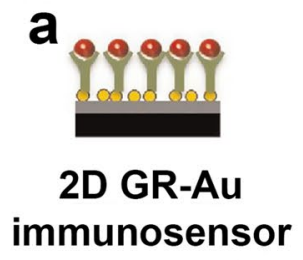

b

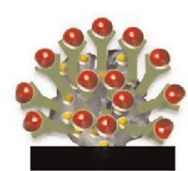

3D GR-Au immunosensor
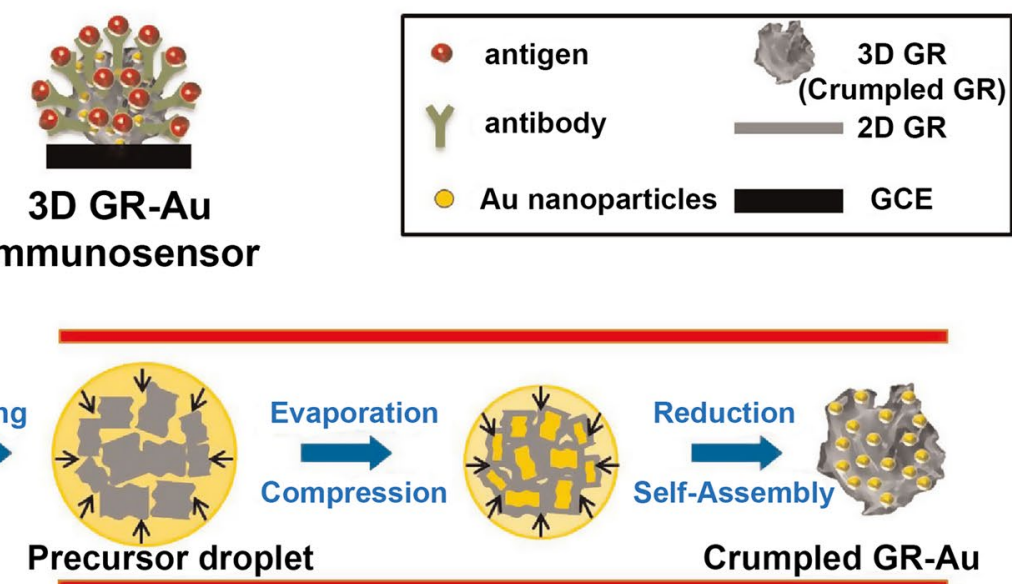

\section{Colloidal mixture Graphene oxide Au precursor}

C
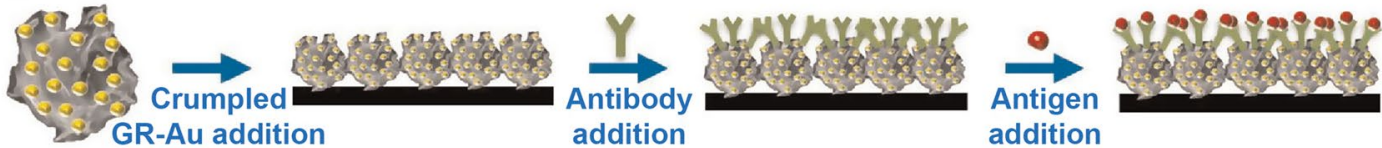
addition addition

Fig. 2 Schematic illustration of Label-free electrochemical immunosensors for PC protein biomarkers based on: A graphene-methylene blue nanocomposite, Reprinted with permission from [93], Copyright 2011 Elsevier. B graphene-Au nanocomposite (Reprinted with permission from [94]. Copyright 2014 Elsevier) 


\section{A}

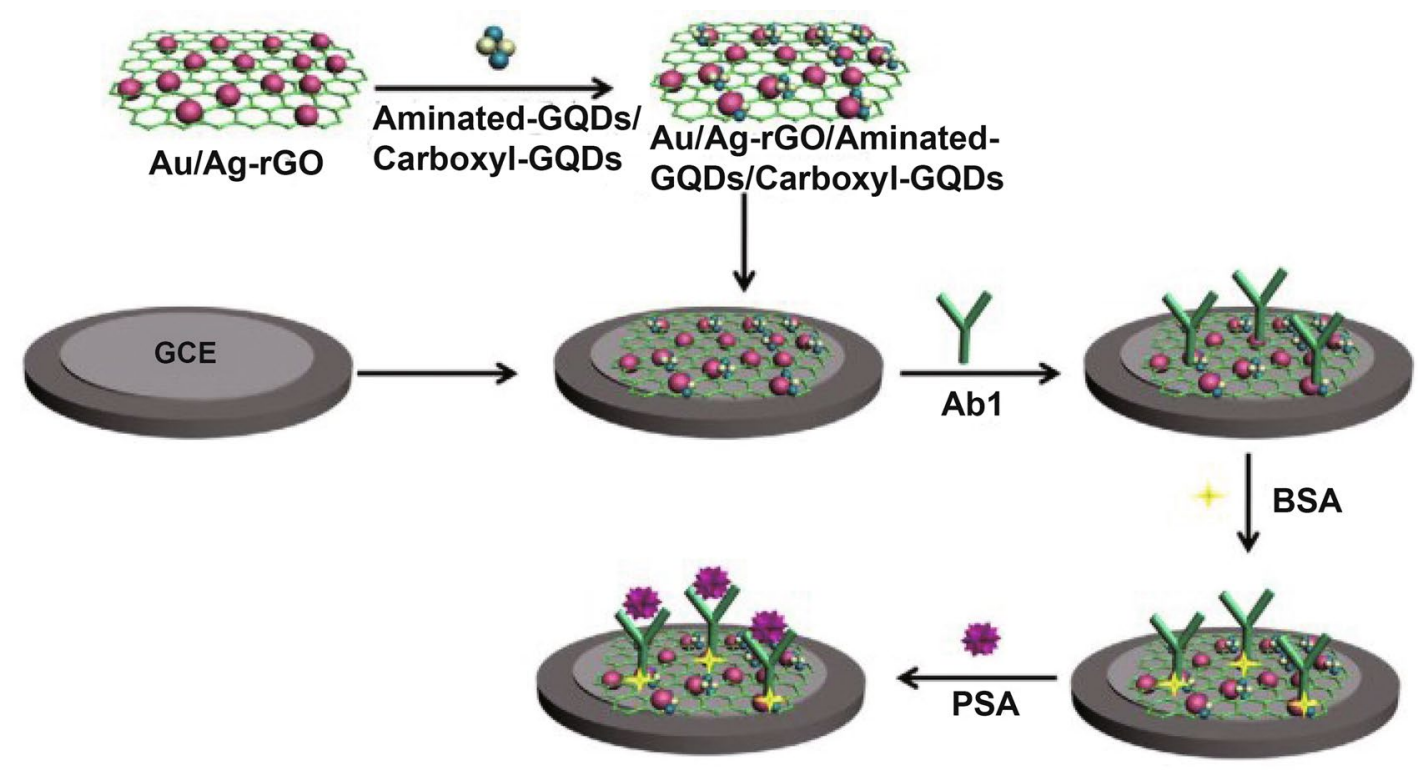

B
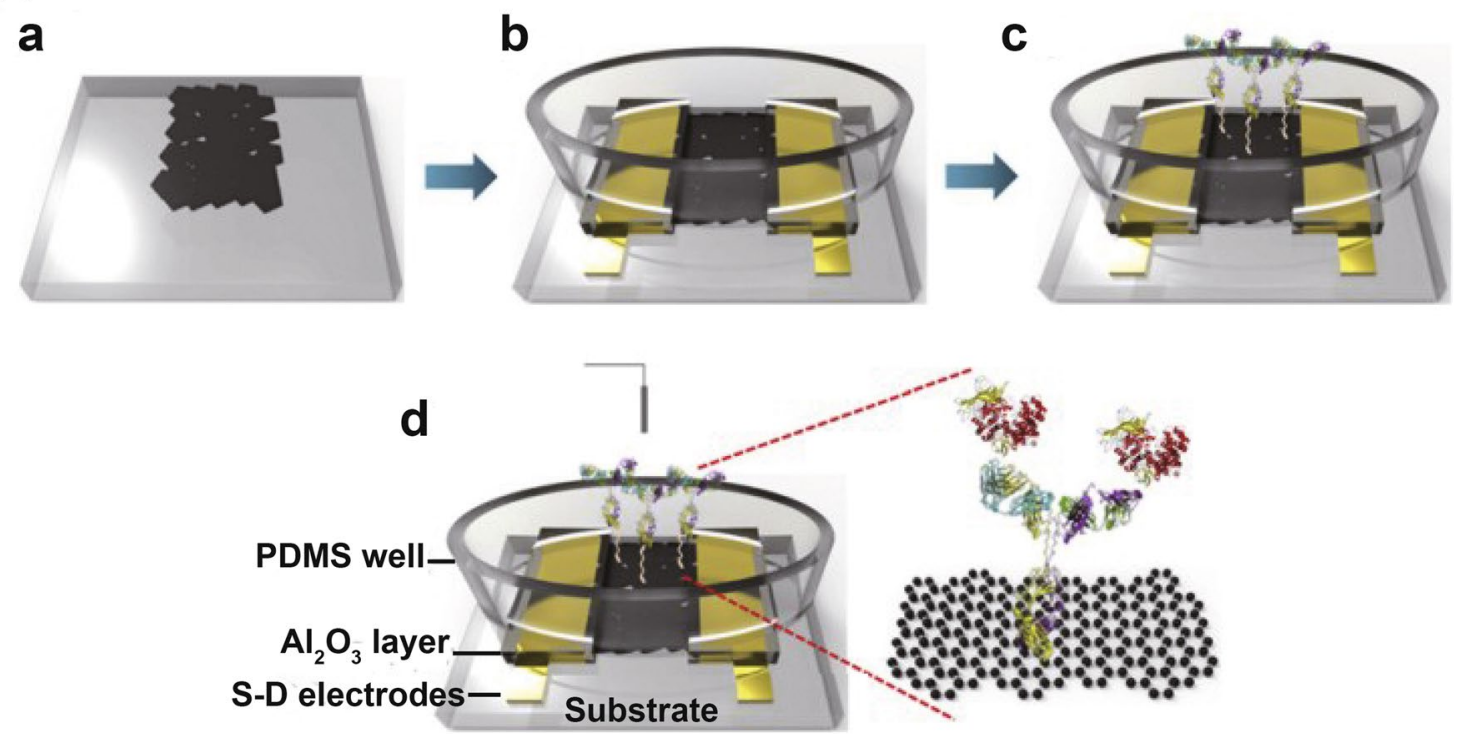

Fig. 3 Illustration of PSA immunosensor fabrication process. A An ECL immunosensor on the electrode surface modified with Au/Ag-rGO, Reprinted with permission from [96]. B FET immunosensor on an rGO channel (Reprinted with permission from [105]. Copyright 2012 Elsevier)

capture the target molecules [106]. The very famous DNA probe in PC biosensor is DNA aptamer [10, 107109], which is a special single-strand DNA (ssDNA) isolated from DNA/RNA libraries of random sequence, by using an in vitro selection process called systematic evolution of ligands by exponential enrichment (SELEX) [110-113].

As the first step toward an aptasensing platform, scientists developed several different strategies to assemble the DNA aptamer onto the electrode as the key recognition element [114-117]. In many reported studies, graphene-based nanocomposites were firstly prepared consisting of graphene and another combing material. For example, Bafrooei et al. modified the electrode with rGOmulti-walled carbon nanotube (MWCNT) nanocomposite and then produced a layer of gold nanoparticles (AuNPs) through electrochemical reduction under $-0.2 \mathrm{~V}$ in $\mathrm{HAuCl}_{4}$, then SH-labeled DNA aptamer was combined to $\mathrm{Au}$ on the electrode surface. Finally, their aptasensor achieved $1.0 \mathrm{pg} / \mathrm{mL}$ limit of detection (LOD) by using both DPV and ESI methods. Different chemical reactions were applied for the assembling of DNA onto graphene 
materials. Branched polyethylenimine (PEI) was applied by Pan et al. to connect thiol-mediated ssDNA onto carboxylated GO for PSA detection [118]. Recently, EDCNHS coupling was applied by Settu et al. to combine DNA probe onto a screen-printed carbon-graphene-modified electrode of the detection of EN2 protein [119].

\section{Graphene-based composites}

for signal-amplification

Peroxidase-like activity of $\mathrm{GO}$

In 2010, Qu's group firstly reported the peroxidase-like activity of GO (Fig. 4a) [120]. Before long, Yang and coworkers found GO was capable of catalyzing the oxidation

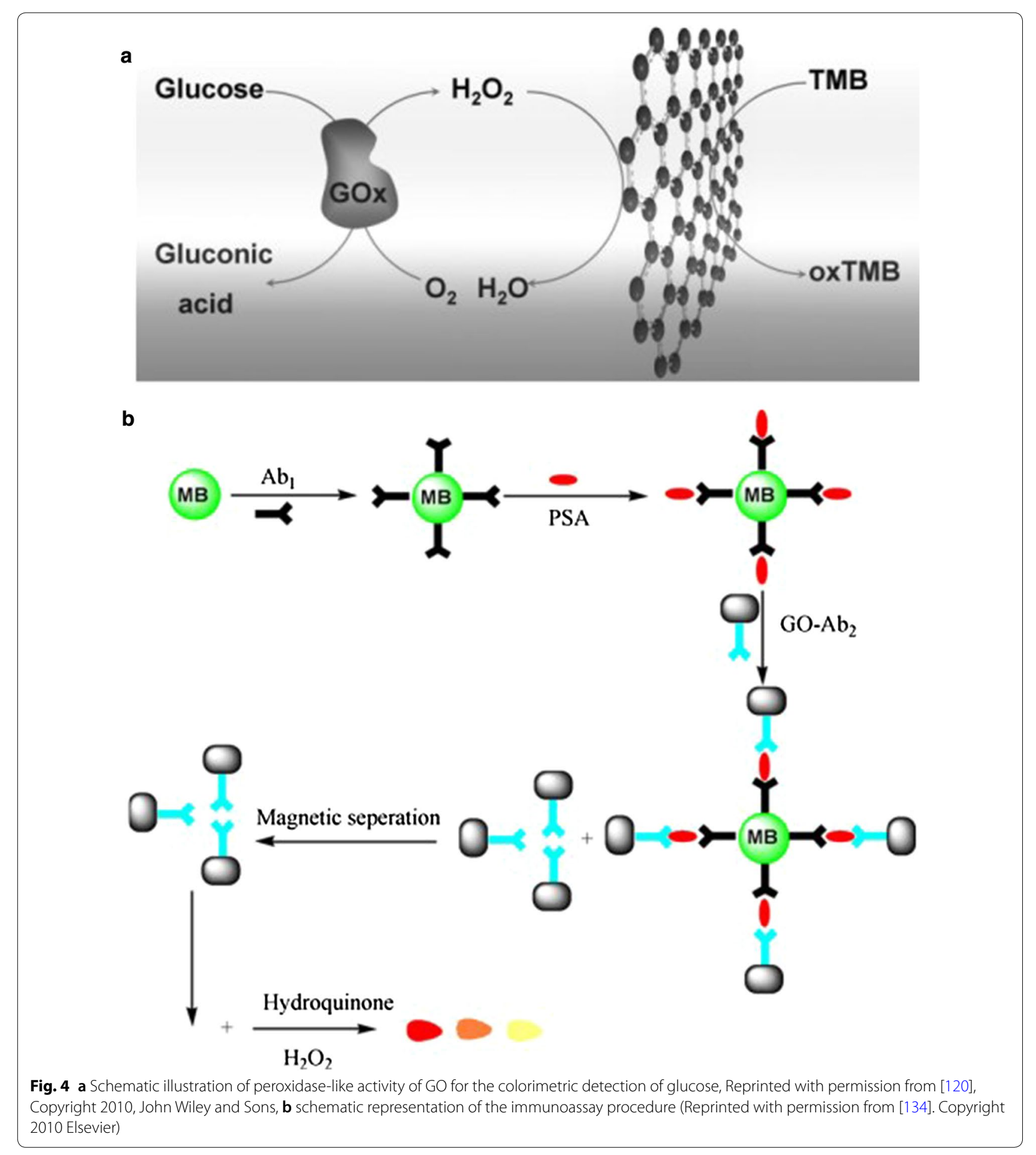


of hydroquinone with the assistant of $\mathrm{H}_{2} \mathrm{O}_{2}$, producing a brown color solution. Thus, they produced an antibodyfunctionalized GO as the signal tag and developed a sandwich-type colorimetric immunoassay for the detection of PSA. In their work [121], an immunocomplex was established when PSA combined GO with secondary anti-PSA $\left(\mathrm{GO}-\mathrm{Ab}_{2}\right)$ and magnetic bead $(\mathrm{MB})$ with primary anti-PSA antibody $\left(\mathrm{MB}-\mathrm{Ab}_{1}\right)$. After the separation in a magnetic field, the color signal was detected corresponding to the concentration of PSA. Their simple immunoassay can be detected by naked eyes (Fig. 4b).

\section{Graphene materials being applied as the carrier of signal tags}

Many recent studies applied graphene-related materials as excellent carriers for the construction of novel nanocomposites for biosensor signal amplification [122-124]. These graphene-based composites were developed by combining graphene or its derivates with metal oxides, metal nanoparticles, or conductive polymers, etc., and this kind of composites showed unique catalytic/ chemical activity [86], that has been widely applied in PC biosensors [125].

Han et al. developed a novel signal tag for PSA and free PSA (fPSA) detection, by using onion-like mesoporous graphene sheets (O-GS) as the carrier of different AuNPbased nanohybrids [126]. As the novel O-GS have multilayer lamellar structure, large surface-to-volume ratio, and excellent electronic transport properties, two kinds of redox nanocomposites were attached to the surface of O-GS, which could accelerate the electron transfer rate and enhance the immobilization amount of enzyme and detection antibodies. Sun et al. reported a signal label by combining bovine serum albumin (BSA)-stabilized silver nanoparticles onto $\mathrm{ZnO}$ nanorods modified rGO, and the AgNPs in the composite showed super catalytic performance toward hydrogen peroxide $\left(\mathrm{H}_{2} \mathrm{O}_{2}\right)$, generating a current signal [127]. Feng et al. developed a sandwichtype electrochemical immunosensor for the detection of PSA. In their work, a GO platform (Au@Th/GO) was used to immobilize primary antibodies and accelerate the electron transfer on the electrode interface. An

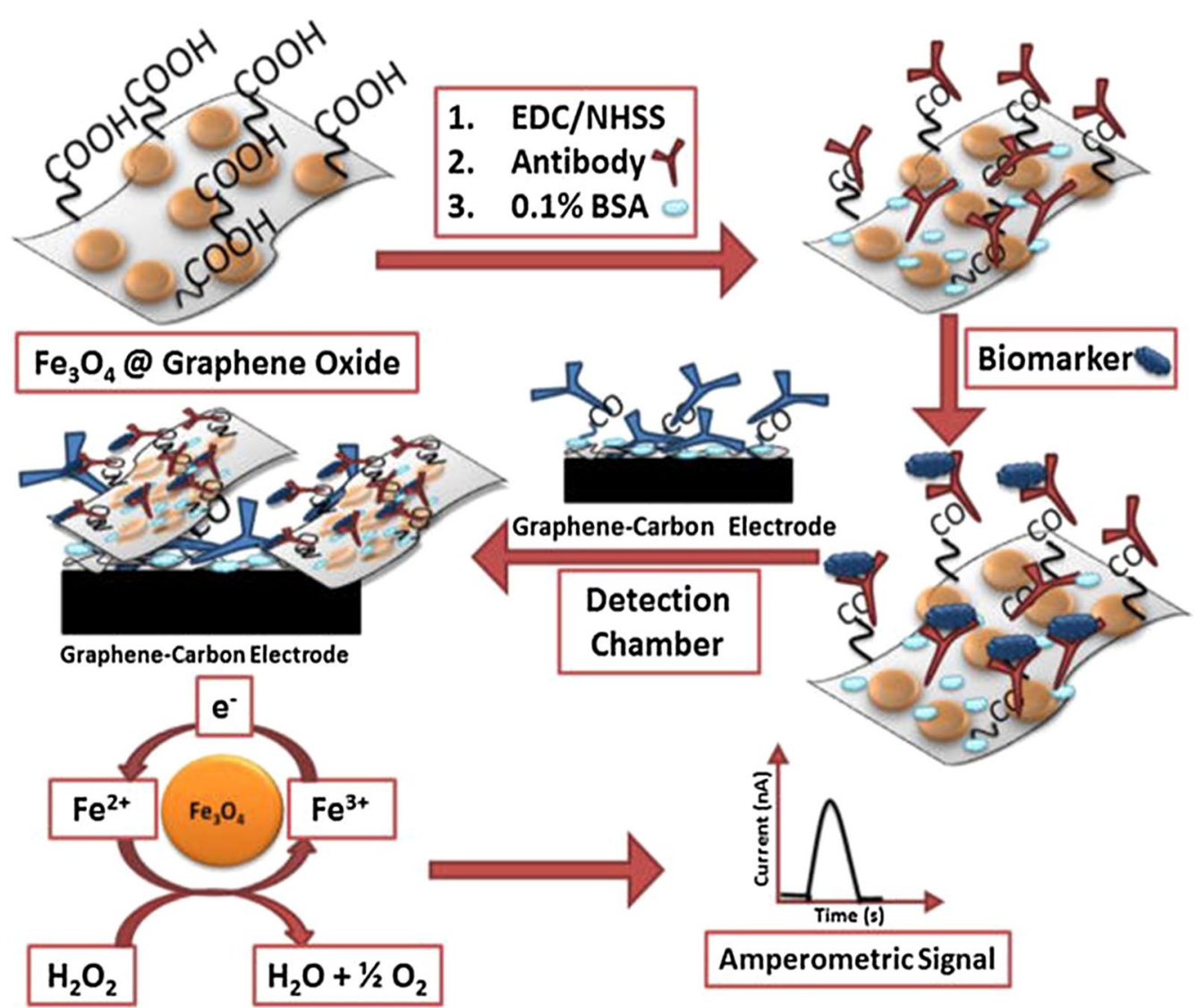

Fig. 5 Protein capture and detection mediated by Fe $\mathrm{O}_{4} @ \mathrm{GO}$ sheets. Proteins captured by Fe $\mathrm{O}_{4} @ \mathrm{GO}$ decorated with detection antibodies. Composite with biomarker was then captured on the sensor surfaces coated with graphene and capture antibodies. Amperometric signal was generated by injecting $100 \mu \mathrm{L} 5 \mathrm{mM} \mathrm{H}_{2} \mathrm{O}_{2}$ (Reprinted with permission from [129]. Copyright 2016 Elsevier) 
rGO-based nanocomposite ( $\mathrm{PtCu} @ \mathrm{rGO} / \mathrm{g}-\mathrm{C}_{3} \mathrm{~N}_{4}$ ) with large surface area, good biocompatibility, and excellent conductivity were used as labels for combining secondary antibodies and amplifying signals. Then secondary antibodies were combined onto this platform and signals were amplified from $\mathrm{H}_{2} \mathrm{O}_{2}$ reduction [128].

Sharafeldin et al. [129] assembled $\mathrm{Fe}_{3} \mathrm{O}_{4}$ nanoparticles together with antibody onto GO sheets to produce a multi-function nanocomposite (Fig. 5). When the GOantibody- $\mathrm{Fe}_{3} \mathrm{O}_{4}$ nanocomposite specifically combined to PSA and PSMA proteins, the resulted complex could be isolated in a magnetic field and delivered in microfluidic channel to an electrochemical detection cell. The $\mathrm{Fe}_{3} \mathrm{O}_{4}-$ GO particles subsequently catalyze $\mathrm{H}_{2} \mathrm{O}_{2}$ reduction, generating a current signal. Improved LOD of $15 \mathrm{fg} / \mathrm{mL}$ of PSA and $4.8 \mathrm{fg} / \mathrm{mL}$ of PSMA was achieved, which was 1000-times better than previously reported PSA biosensors using $\mathrm{Fe}_{3} \mathrm{O}_{4}$ only, probably because $\mathrm{GO}$ carried more $\mathrm{Fe}_{3} \mathrm{O}_{4}$ particles and thus dramatically increased the electrochemical signal.

\section{Conclusion and future perspectives}

Biosensors for cancer biomarker detection opened a new avenue for the POC PC detection. In spite of their very short history, graphene-based materials have successfully demonstrated their unique advantages in biosensors for PC protein biomarkers. This review has summarized recent advances, challenges, and trends in the application of graphene-based materials for biosensing of PC protein biomarkers. In this review, the commonly used PC protein biomarkers for biosensor, the unique properties of graphene and the roles of graphene-based materials for biosensing were introduced. Among various PC protein biomarkers, PSA was the most frequently selected target for PC detection biosensor construction. Most studies focused on single biomarker detection and studies on detection of multiple biomarkers are limited. A variety of graphene-based materials such as pristine graphene, functionalized graphene (GO, rGO, GODs) were used in PC biosensor development and most of them were combined with other nanomaterials like nanoparticles. We have also summarized various strategies and approaches which can be used for graphene-based biosensor development. Graphene-based materials were used not only for novel biosensor interfaces construction but also as excellent carriers for the construction of novel nanocomposites for signal amplification. In most of the cases, graphene-based biosensors have exhibited satisfactory biocompatibility towards the bioactive species and remarkable performance with high sensitivities, wide linear detection ranges, low detection limits and long-term stabilities (Table 1). As other 2D materials have now been explored, we believe that more $2 \mathrm{D}$

Table 1 Current generation reports of graphene-based biosensors for PC biomarker detection

\begin{tabular}{|c|c|c|c|c|c|}
\hline Technique & Receptor system & Target proteins & LOD & Detection ranges & References \\
\hline ECHEM & rGO-MWCNT/AuNPs & PSA & $1.0 \mathrm{pg} / \mathrm{mL}$ & $\begin{array}{l}(0.005-20) \mathrm{ng} / \mathrm{mL} \text { for } \mathrm{DPV},(0.005- \\
100) \mathrm{ng} / \mathrm{mL} \text { for ElS }\end{array}$ & {$[132]$} \\
\hline ECHEM & rGO/Ag@BSA & HCG, PSA, CEA & $\begin{array}{l}0.0007 \mathrm{mlU} / \mathrm{mL} \text { for } \mathrm{HCG}, 0.35 \mathrm{pg} / \\
\mathrm{mL} \text { for PSA, and } 0.33 \mathrm{pg} / \mathrm{mL} \\
\text { for CEA }\end{array}$ & $\begin{array}{l}\text { (0.002-120) } \mathrm{mIU} / \mathrm{mL} \text { for } \mathrm{HCG} \\
(0.001-110) \mathrm{ng} / \mathrm{mL} \text { for PSA, } \\
(0.001-100) \mathrm{ng} / \mathrm{mL} \text { for CEA }\end{array}$ & {$[127]$} \\
\hline ECHEM & $\begin{array}{l}\text { Au@Th/GO,PtCu@rGO/graphitic } \\
\text { carbon nitride }\end{array}$ & PSA & $16.6 \mathrm{fg} / \mathrm{mL}$ & $50 \mathrm{fg} / \mathrm{mL}-40 \mathrm{ng} / \mathrm{mL}$ & {$[128]$} \\
\hline ECHEM & GO/ssDNA/PLLA NPs & VEGF, PSA & - & $\begin{array}{l}(0.05-100) \mathrm{ng} / \mathrm{mL} \text { for VEGF, } \\
(1-100) \mathrm{ng} / \mathrm{mL} \text { for PSA }\end{array}$ & {$[118]$} \\
\hline ECHEM & $\mathrm{Fe}_{3} \mathrm{O}_{4} / \mathrm{PDDA} / \mathrm{GO}$ & PSA, PSMA & $\begin{array}{l}15 \mathrm{fg} / \mathrm{mL} \text { for PSA, } 4.8 \mathrm{fg} / \mathrm{mL} \text { for } \\
\text { PSMA }\end{array}$ & $\begin{array}{l}(61 \mathrm{fg} / \mathrm{mL}-3.9 \mathrm{pg} / \mathrm{mL}) \text { for PSA, } \\
(9.8 \mathrm{fg} / \mathrm{mL}-10 \mathrm{pg} / \mathrm{mL}) \text { for PSMA }\end{array}$ & {$[129]$} \\
\hline ECHEM & $\begin{array}{l}\text { Au@PBNPs/O-GS, Au@NiNPs/O- } \\
\text { GS }\end{array}$ & fPSA, PSA & $\begin{array}{l}6.7 \mathrm{pg} / \mathrm{mL} \text { for fPSA, } 3.4 \mathrm{pg} / \mathrm{mL} \\
\text { for PSA }\end{array}$ & $\begin{array}{r}(0.02-10) \mathrm{ng} / \mathrm{mL} \text { for fPSA } \\
(0.01-50) \mathrm{ng} / \mathrm{mL} \text { for PSA }\end{array}$ & {$[126]$} \\
\hline ECHEM & $\mathrm{GS} / \mathrm{DA} / \mathrm{Fe}_{3} \mathrm{O}_{4} / \mathrm{FC}$ & PSA & $2 \mathrm{pg} / \mathrm{mL}$ & $(0.01-40) \mathrm{ng} / \mathrm{mL}$ & {$[92]$} \\
\hline ECHEM & Carbon-graphene/aptamer & EN2 protein & $38.5 \mathrm{nM}$ & $(35-185) \mathrm{nM}$ & {$[119]$} \\
\hline ECHEM & GS-MB-CS & PSA & $13 \mathrm{pg} / \mathrm{mL}$ & $(0.05-5.00) \mathrm{ng} / \mathrm{mL}$ & {$[93]$} \\
\hline ECHEM & 3D graphene/Au & PSA & $0.59 \mathrm{ng} / \mathrm{mL}$ & $(0-10) \mathrm{ng} / \mathrm{mL}$ & {$[94]$} \\
\hline FET & rGO & PSA-ACT & $100 \mathrm{fg} / \mathrm{mL}$ & $\left(10^{-7}-1\right) \mu \mathrm{g} / \mathrm{mL}$ & {$[105]$} \\
\hline Fluorescence & GQDs-NR & $\mathrm{ACP}$ & $28 \mu \mathrm{U} / \mathrm{mL}$ & $(0-1500) \mu U / m L$ & {$[133]$} \\
\hline Fluorescence & GO/peptide/FITC & PSA & $0.3 \mathrm{nM}$ & $(0-20) n M$ & {$[64]$} \\
\hline $\mathrm{ECL}$ & $\begin{array}{l}\text { Au/Ag-rGO/aminated-GQDs/ } \\
\text { carboxyl-GQDs }\end{array}$ & PSA & $0.29 \mathrm{pg} / \mathrm{mL}$ & $1 \mathrm{pg} / \mathrm{mL}-10 \mathrm{ng} / \mathrm{mL}$ & {$[96]$} \\
\hline $\mathrm{ECL}$ & graphene & PSA & $8 \mathrm{pg} / \mathrm{mL}$ & $10 \mathrm{pg} / \mathrm{mL}-8 \mathrm{ng} / \mathrm{mL}$ & {$[95]$} \\
\hline Colorimetric & $\mathrm{GO} / \mathrm{MB}$ & PSA & - & - & [134] \\
\hline
\end{tabular}


materials like $\mathrm{MoS}_{2}$ could be employed and integrated into biosensors for PC biomarker detection in the upcoming future.

Although tremendous progress has been made in the past a few years of graphene-based biosensors for PC detection, there still remain some challenges. Firstly, PSA has been demonstrated not a specific biomarker in prostate cancer early screening. As a result, detection of multiple biomarkers is crucial for precise diagnosis and prognosis of PC $[130,131]$. More attention should be paid to studies on the simultaneous detection of multiple biomarkers in the future. In addition, there are only a few studies on PC biomarker detection in different body fluid. To improve the accuracy and practicability of the diagnosis, more studies are expected to perform biomarker detection in different body fluid.

\section{Acknowledgements}

This work was supported by National Key R\&D Program of China (2017YFF0204605, 2017YFF0204603, 2018YFF0212803), National Natural Science Foundation of China (No. 21775104), and Shanghai Rising-Star Program (16QB1403100). This work was supported by grants from Vinnova, the Danish Research Council FTP and Olle Engkvist Foundation to IM.

\section{Authors' contributions}

LX contributed to the conception of the review and manuscript writing YLW and SP contributed to the data collection. VRSSM contributed to the manuscript preparation. IM helped revising the manuscript. YL, MD, SZR and $W L$ helped interpreting the data with constructive discussions. GL contributed to the conception of the review. All authors read and approved the final manuscript.

\section{Funding}

This work was supported by National Key R\&D Program of China (2017YFF0204605, 2017YFF0204603, 2018YFF0212803), National Natural Science Foundation of China (No. 21775104), and Shanghai Rising-Star Program (16QB1403100). This work was supported by grants from Vinnova, the Danish Research Council FTP and Olle Engkvist Foundation to IM.

\section{Availability of data and materials}

Not applicable

\section{Competing interests}

The authors declare that they have no competing interests.

\begin{abstract}
Author details
${ }^{1}$ Laboratory of Biometrory, Division of Chemistry and lonizing Radiation Measurement Technology, Shanghai Institute of Measurement and Testing Technology, Shanghai 201203, People's Republic of China. ${ }^{2}$ Division of Systems and Synthetic Biology, Department of Biology and Biological Engineering, Chalmers University of Technology, 41126 Gothenburg, Sweden. ${ }^{3}$ The Novo Nordisk Foundation Center for Biosustainability, Technical University of Denmark, 2800 Lyngby, Denmark.
\end{abstract}

Received: 21 August 2018 Accepted: 15 July 2019

Published online: 03 September 2019

\section{References}

1. Healy DA, Hayes CJ, Leonard P, McKenna L, O'Kennedy R (2007) Biosensor developments: application to prostate-specific antigen detection. Trends Biotechnol 25:125-131

2. Siegel RL, Miller KD, Jemal A (2017) Cancer statistics, 2017. CA Cancer J Clin 67:7-30
3. Siegel RL, Miller KD, Jemal A (2018) Cancer statistics, 2018. CA Cancer J Clin 68:7-30

4. Kim EH, Andriole GL (2018) Prostate cancer review. Mo Med 115:131

5. Pettersson A, Robinson D, Garmo H, Holmberg L, Stattin P (2018) Age at diagnosis and prostate cancer treatment and prognosis: a populationbased cohort study. Ann Oncol 29:377-385

6. Lemanska A, Dearnaley DP, Jena R, Sydes MR, Faithfull S (2018) Older age, early symptoms and physical function are associated with the severity of late symptom clusters for men undergoing radiotherapy for prostate cancer. Clin Oncol (R Coll Radiol) 30:334-345

7. Bashir MN (2015) Epidemiology of prostate cancer. Asian Pac J Cancer Prev 16:5137-5141

8. Pernar CH, Ebot EM, Wilson KM, Mucci LA (2018) The epidemiology of prostate cancer. Cold Spring Harb Perspect Med. https://doi. org/10.1101/cshperspect.a030361

9. Sammon JD, Serrell EC, Karabon P, Leow JJ, Abdollah F, Weissman JS, Han PKJ, Hansen M, Menon M, Trinh QD (2018) Prostate cancer screening in early medicaid expansion states. J Urol 199:81-88

10. Carroll PR, Parsons JK, Andriole G, Bahnson RR, Castle EP, Catalona WJ, Dahl DM, Davis JW, Epstein Jl, Etzioni RB, Farrington T, Hemstreet GP, Kawachi MH, Kim S, Lange PH, Loughlin KR, Lowrance W, Maroni P, Mohler J, Morgan TM, Moses KA, Nadler RB, Poch M, Scales C, Shaneyfelt TM, Smaldone MC, Sonn G, Sprenkle P, Vickers AJ, Wake R, Shead DA, Freedman-Cass DA (2016) Prostate cancer early detection, version 2.2016. J Natl Compr Cancer Netw 14:509-519

11. Partin AW (2013) Early detection of prostate cancer continues to support rational, limited screening. J Urol 190:427-428

12. Cremers RG, Eeles RA, Bancroft EK, Ringelberg-Borsboom J, Vasen HF, Van Asperen CJ, Committee IS, Schalken JA, Verhaegh GW, Kiemeney LA (2015) The role of the prostate cancer gene 3 urine test in addition to serum prostate-specific antigen level in prostate cancer screening among breast cancer, early-onset gene mutation carriers. Urol Oncol 33:202 e19-e28

13. Rifai N, Gillette MA, Carr SA (2006) Protein biomarker discovery and validation: the long and uncertain path to clinical utility. Nat Biotechnol 24(8):971-983

14. Ordonez NG (2014) Value of podoplanin as an immunohistochemical marker in tumor diagnosis: a review and update. Appl Immunohistochem Mol Morphol 22:331-347

15. Mitchell PS, Parkin RK, Kroh EM, Fritz BR, Wyman SK, Pogosova-Agadjanyan EL, Peterson A, Noteboom J, O'Briant KC, Allen A, Lin DW, Urban N, Drescher CW, Knudsen BS, Stirewalt DL, Gentleman R, Vessella RL, Nelson PS, Martin DB, Tewari M (2008) Circulating microRNAs as stable blood-based markers for cancer detection. Proc Natl Acad Sci USA 105:10513-10518

16. Bettegowda C, Sausen M, Leary RJ, Kinde I, Wang YX, Agrawal N, Bartlett BR, Wang H, Luber B, Alani RM, Antonarakis ES, Azad NS, Bardelli A, Brem $\mathrm{H}$, Cameron JL, Lee CC, Fecher LA, Gallia GL, Gibbs P, Le D, Giuntoli RL, Goggins M, Hogarty MD, Holdhoff M, Hong SM, Jiao YC, Juhl HH, Kim JJ, Siravegna G, Laheru DA, Lauricella C, Lim M, Lipson EJ, Marie SKN, Netto GJ, Oliner KS, Olivi A, Olsson L, Riggins GJ, Sartore-Bianchi A, Schmidt K, Shih IM, Oba-Shinjo SM, Siena S, Theodorescu D, Tie JN, Harkins TT, Veronese S, Wang TL, Weingart JD, Wolfgang CL, Wood LD, Xing DM, Hruban RH, Wu J, Allen PJ, Schmidt CM, Choti MA, Velculescu VE, Kinzler KW, Vogelstein B, Papadopoulos N, Luis AJ (2014) Detection of circulating tumor DNA in early- and late-stage human malignancies. Sci Transl Med 6(224):224ra24

17. Isbell JM, Jones DR, Li BT (2018) Circulating tumor DNA: A promising biomarker to guide postoperative treatment and surveillance of nonsmall cell lung cancer. J Thorac Cardiovasc Surg 155:2628-2631

18. Wu LL, Chiou CC, Chang PY, Wu JT (2004) Urinary 8-OHdG: a marker of oxidative stress to DNA and a risk factor for cancer, atherosclerosis and diabetics. Clin Chim Acta 339:1-9

19. Monteiro M, Moreira N, Pinto J, Pires-Luis AS, Henrique R, Jeronimo C, Bastos ML, Gil AM, Carvalho M, Guedes de Pinho P (2017) GC-MS metabolomics-based approach for the identification of a potential VOC-biomarker panel in the urine of renal cell carcinoma patients. J Cell Mol Med 21(9):2092-2105

20. Natarajan H, Kumar L, Bakhshi S, Sharma A, Velpandian T, Kabra M, Gogia A, Ranjan Biswas N, Gupta YK (2018) Imatinib trough levels: a potential biomarker to predict cytogenetic and molecular response 
in newly diagnosed patients with chronic myeloid leukemia. Leuk Lymphoma 60:1-8

21. Yu M, Stott S, Toner M, Maheswaran S, Haber DA (2011) Circulating tumor cells: approaches to isolation and characterization. J Cell Biol 192:373-382

22. Inoue M, Otsuka K, Shibata H (2016) Circulating tumor cell count as a biomarker of a specific gastric cancer subgroup characterized by bone metastasis and/or disseminated intravascular coagulation-an early indicator of chemotherapeutic response. Oncol Lett 11:1294-1298

23. Wu L, Qu X (2015) Cancer biomarker detection: recent achievements and challenges. Chem Soc Rev 44:2963-2997

24. Severi G, FitzGerald LM, Muller DC, Pedersen J, Longano A, Southey MC, Hopper JL, English DR, Giles GG, Mills J (2014) A three-protein biomarker panel assessed in diagnostic tissue predicts death from prostate cancer for men with localized disease. Cancer Med 3:1266-1274

25. Shui B, Tao D, Florea A, Cheng J, Zhao Q, Gu Y, Li W, Jaffrezic-Renault N, Mei Y, Guo Z (2018) Biosensors for Alzheimer's disease biomarker detection: a review. Biochimie 147:13-24

26. Lin PY, Cheng KL, McGuffin-Cawley JD, Shieu FS, Samia AC, Gupta S, Cooney M, Thompson CL, Liu CC (2012) Detection of Alpha-MethylacylCoA Racemase (AMACR), a biomarker of prostate cancer, in patient blood samples using a nanoparticle electrochemical biosensor. Biosensors (Basel) 2:377-387

27. Parra-Cabrera C, Samitier J, Homs-Corbera A (2016) Multiple biomarkers biosensor with just-in-time functionalization: application to prostate cancer detection. Biosens Bioelectron 77:1192-1200

28. Narwal V, Kumar P, Joon P, Pundir CS (2018) Fabrication of an amperometric sarcosine biosensor based on sarcosine oxidase/chitosan/ CuNPs/c-MWCNT/Au electrode for detection of prostate cancer. Enzyme Microb Technol 113:44-51

29. Geim AK, Novoselov KS (2007) The rise of graphene. Nat Mater 6:183-191

30. Pena-Bahamonde J, Nguyen HN, Fanourakis SK, Rodrigues DF (2018) Recent advances in graphene-based biosensor technology with applications in life sciences. J Nanobiotechnol 16:75

31. Kim J, Park SJ, Min DH (2017) Emerging approaches for graphene oxide biosensor. Anal Chem 89:232-248

32. Tarro G, Perna A, Esposito C (2005) Early diagnosis of lung cancer by detection of tumor liberated protein. J Cell Physiol 203:1-5

33. Borrebaeck CA (2017) Precision diagnostics: moving towards protein biomarker signatures of clinical utility in cancer. Nat Rev Cancer 17:199-204

34. Surinova S, Radova L, Choi M, Srovnal J, Brenner H, Vitek O, Hajduch M, Aebersold R (2015) Non-invasive prognostic protein biomarker signatures associated with colorectal cancer. EMBO Mol Med 7:1153-1165

35. Morin PJ (2005) Claudin proteins in human cancer: promising new targets for diagnosis and therapy. Cancer Res 65:9603-9606

36. Tang T, Yang C, Brown HE, Huang J (2018) Circulating heat shock protein 70 is a novel biomarker for early diagnosis of lung cancer. Dis Markers 2018:6184162

37. Jung YJ, Katilius E, Ostroff RM, Kim Y, Seok M, Lee S, Jang S, Kim WS, Choi CM (2017) Development of a protein biomarker panel to detect nonsmall-cell lung cancer in Korea. Clin Lung Cancer 18:e99-e107

38. Yang Z, Li DM, Xie Q, Dai DQ (2015) Protein expression and promoter methylation of the candidate biomarker TCF21 in gastric cancer. J Cancer Res Clin Oncol 141:211-220

39. Zhurauski P, Arya SK, Jolly P, Tiede C, Tomlinson DC, Ko Ferrigno P, Estrela $P$ (2018) Sensitive and selective Affimer-functionalised interdigitated electrode-based capacitive biosensor for Her4 protein tumour biomarker detection. Biosens Bioelectron 108:1-8

40. Arya SK, Kongsuphol P, Park MK (2017) Off surface matrix based on-chip electrochemical biosensor platform for protein biomarker detection in undiluted serum. Biosens Bioelectron 92:542-548

41. Ray S, Senapati T, Sahu S, Bandyopadhyaya R, Anand R (2018) Design of ultrasensitive protein biosensor strips for selective detection of aromatic contaminants in environmental wastewater. Anal Chem 90:8960-8968

42. Stamey TA, Ekman PE, Blankenstein MA, Cooper EH, Kontturi M, Lilja H, Oesterling JE, Stenman UH, Turkes A (1994) Tumor markers. In: Consensus conference on diagnosis and prognostic parameters in localized prostate cancer. Stockholm, Sweden, May 12-13, 1993. Scand J Urol Nephrol Suppl 162:73-87. (discussion 115-127)
43. Bok RA, Small EJ (2002) Bloodborne biomolecular markers in prostate cancer development and progression. Nat Rev Cancer 2:918-926

44. Hernandez J, Thompson IM (2004) Prostate-specific antigen: a review of the validation of the most commonly used cancer biomarker. Cancer 101:894-904

45. Liu N, Liang W, Ma X, Li X, Ning B, Cheng C, Ou G, Wang B, Zhang J, Gao $Z$ (2013) Simultaneous and combined detection of multiple tumor biomarkers for prostate cancer in human serum by suspension array technology. Biosens Bioelectron 47:92-98

46. Vergho DC, Heine K, Wolff JM (2005) The role of PSA in diagnosis of prostate cancer and its recurrence. Pathologe 26:473-478

47. Bantis A, Grammaticos P (2012) Prostatic specific antigen and bone scan in the diagnosis and follow-up of prostate cancer. Can diagnostic significance of PSA be increased? Hell J Nucl Med 15:241-246

48. Perez-lbave DC, Burciaga-Flores CH, Elizondo-Riojas MA (2018) Prostatespecific antigen (PSA) as a possible biomarker in non-prostatic cancer: a review. Cancer Epidemiol 54:48-55

49. Polascik TJ, Oesterling JE, Partin AW (1999) Prostate specific antigen: a decade of discovery-what we have learned and where we are going. J Urol 162:293-306

50. Stamey TA, Caldwell M, McNeal JE, Nolley R, Hemenez M, Downs $J$ (2004) The prostate specific antigen era in the United States is over for prostate cancer: what happened in the last 20 years? J Urol 172:1297-1301

51. Stephan C, Ralla B, Jung K (2014) Prostate-specific antigen and other serum and urine markers in prostate cancer. Biochim Biophys Acta 1846:99-112

52. Israeli RS, Powell CT, Fair WR, Heston WD (1993) Molecular cloning of a complementary DNA encoding a prostate-specific membrane antigen. Cancer Res 53:227-230

53. Bostwick DG, Pacelli A, Blute M, Roche P, Murphy GP (1998) Prostate specific membrane antigen expression in prostatic intraepithelial neoplasia and adenocarcinoma: a study of 184 cases. Cancer 82:2256-2261

54. Wright GL Jr, Haley C, Beckett ML, Schellhammer PF (1995) Expression of prostate-specific membrane antigen in normal, benign, and malignant prostate tissues. Urol Oncol 1:18-28

55. Violet JA, Hofman MS (2017) Prostate-specific membrane antigen from diagnostic to therapeutic target: radionuclide therapy comes of age in prostate cancer. BJU Int 120:310-312

56. Ristau BT, O'Keefe DS, Bacich DJ (2014) The prostate-specific membrane antigen: lessons and current clinical implications from 20 years of research. Urol Oncol 32:272-279

57. Arsenault F, Beauregard JM, Pouliot F (2018) Prostate-specific membrane antigen for prostate cancer theranostics: from imaging to targeted therapy. Curr Opin Support Palliat Care 12(3):359-365

58. Afaq A, Bomanji J (2018) Prostate-specific membrane antigen positron emission tomography in the management of recurrent prostate cancer. Br Med Bull 128:37-48

59. Reiter RE, Gu Z, Watabe T, Thomas G, Szigeti K, Davis E, Wahl M, Nisitani S, Yamashiro J, Le Beau MM, Loda M, Witte ON (1998) Prostate stem cell antigen: a cell surface marker overexpressed in prostate cancer. Proc Natl Acad Sci USA 95:1735-1740

60. Yang X, Guo Z, Liu Y, Si T, Yu H, Li B, Tian W (2014) Prostate stem cell antigen and cancer risk, mechanisms and therapeutic implications. Expert Rev Anticancer Ther 14:31-37

61. Ross S, Spencer SD, Holcomb I, Tan C, Hongo J, Devaux B, Rangell L, Keller GA, Schow P, Steeves RM, Lutz RJ, Frantz G, Hillan K, Peale F, Tobin P, Eberhard D, Rubin MA, Lasky LA, Koeppen H (2002) Prostate stem cell antigen as therapy target: tissue expression and in vivo efficacy of an immunoconjugate. Cancer Res 62:2546-2553

62. Bargao Santos P, Patel HR (2014) Prostate stem cell antigen-novel biomarker and therapeutic target? Expert Rev Anticancer Ther 14:5-7

63. Marszall MP, Sroka W, Adamowski M, Slupski P, Jarzemski P, Siodmiak J. Odrowaz-Sypniewska G (2015) Engrailed-2 protein as a potential urinary prostate cancer biomarker: a comparison study before and after digital rectal examination. Eur J Cancer Prev 24:51-56

64. Feng T, Feng D, Shi W, Li X, Ma H (2012) A graphene oxide-peptide fluorescence sensor for proteolytically active prostate-specific antigen. Mol BioSyst 8:1441-1445

65. Sadlowski C, Balderston S, Sandhu M, Hajian R, Liu C, Tran TP, Conboy MJ, Paredes J, Murthy N, Conboy IM, Aran K (2018) Graphene-based 
biosensor for on-chip detection of bio-orthogonally labeled proteins to identify the circulating biomarkers of aging during heterochronic parabiosis. Lab Chip 18:3230-3238

66. Wang L, Zhang Y, Wu A, Wei G (2017) Designed graphene-peptide nanocomposites for biosensor applications: a review. Anal Chim Acta 985:24-40

67. Liu Y, Dong X, Chen P (2012) Biological and chemical sensors based on graphene materials. Chem Soc Rev 41:2283-2307

68. Ryoo SR, Yim Y, Kim YK, Park IS, Na HK, Lee J, Jang H, Won C, Hong S, Kim SY, Jeon NL, Song JM, Min DH (2018) High-throughput chemical screening to discover new modulators of microRNA expression in living cells by using graphene-based biosensor. Sci Rep 8:11413

69. Klukova L, Filip J, Belicky S, Vikartovska A, Tkac J (2016) Graphene oxidebased electrochemical label-free detection of glycoproteins down to aM level using a lectin biosensor. Analyst 141:4278-4282

70. Xie H, Li YT, Lei YM, Liu YL, Xiao MM, Gao C, Pang DW, Huang WH, Zhang ZY, Zhang GJ (2016) Real-time monitoring of nitric oxide at single-cell level with porphyrin-functionalized graphene field-effect transistor biosensor. Anal Chem 88:11115-11122

71. Bianco A, Cheng HM, Enoki T, Gogotsi Y, Hurt RH, Koratkar N, Kyotani T, Monthioux M, Park CR, Tascon JMD, Zhang J (2013) All in the graphene family - a recommended nomenclature for two-dimensional carbon materials. Carbon 65:1-6

72. Suvarnaphaet P, Pechprasarn S (2017) Graphene-based materials for biosensors: a review. Sensors (Basel). https://doi.org/10.3390/s1710 2161

73. Tabish TA (2018) Graphene-based materials: the missing piece in nanomedicine? Biochem Biophys Res Commun 504:686-689

74. Khalilzadeh B, Shadjou N, Afsharan H, Eskandani M, Nozad Charoudeh H, Rashidi MR (2016) Reduced graphene oxide decorated with gold nanoparticle as signal amplification element on ultra-sensitive electrochemiluminescence determination of caspase-3 activity and apoptosis using peptide based biosensor. Bioimpacts 6:135-147

75. Morales-Narvaez E, Merkoci A (2018) Graphene oxide as an optical biosensing platform: a progress report. Adv Mater 31:e1805043

76. Liu B, Huang PJ, Kelly EY, Liu J (2016) Graphene oxide surface blocking agents can increase the DNA biosensor sensitivity. Biotechnol J 11:780-787

77. Yang G, Li L, Lee WB, Ng MC (2018) Structure of graphene and its disorders: a review. Sci Technol Adv Mater 19:613-648

78. Kumar S, Kumar S, Srivastava S, Yadav BK, Lee SH, Sharma JG, Doval DC, Malhotra BD (2015) Reduced graphene oxide modified smart conducting paper for cancer biosensor. Biosens Bioelectron 73:114-122

79. Seifati SM, Nasirizadeh N, Azimzadeh M (2018) Nano-biosensor based on reduced graphene oxide and gold nanoparticles, for detection of phenylketonuria-associated DNA mutation. IET Nanobiotechnol 12:417-422

80. Munief WM, Lu X, Teucke T, Wilhelm J, Britz A, Hempel F, Lanche R, Schwartz M, Law JKY, Grandthyll S, Muller F, Neurohr JU, Jacobs K, Schmitt M, Pachauri V, Hempelmann R, Ingebrandt S (2018) Reduced graphene oxide biosensor platform for the detection of NT-proBNP biomarker in its clinical range. Biosens Bioelectron 126:136-142

81. Zhang HG, Hu H, Pan Y, Mao JH, Gao M, Guo HM, Du SX, Greber T, Gao HJ (2010) Graphene based quantum dots. J Phys Condens Matter 22:302001

82. Zeng X, Ma S, Bao J, Tu W, Dai Z (2013) Using graphene-based plasmonic nanocomposites to quench energy from quantum dots for signal-on photoelectrochemical aptasensing. Anal Chem 85:11720-11724

83. Zeng L, Wang R, Zhu L, Zhang J (2013) Graphene and CdS nanocomposite: a facile interface for construction of DNA-based electrochemical biosensor and its application to the determination of phenformin. Colloids Surf B Biointerfaces 110:8-14

84. Li Y, Wang X, Gong J, Xie Y, Wu X, Zhang G (2018) Graphene based nanocomposites for efficient photocatalytic hydrogen evolution: insight into the interface toward separation of photogenerated charges. ACS Appl Mater Interfaces 10:43760-43767

85. Li D, Zhang W, Yu X, Wang Z, Su Z, Wei G (2016) When biomolecules meet graphene: from molecular level interactions to material design and applications. Nanoscale 8:19491-19509
86. Zhang Y, Shen J, Li H, Wang L, Cao D, Feng X, Liu Y, Ma Y, Wang L (2016) Recent progress on graphene-based electrochemical biosensors. Chem Rec 16:273-294

87. Korkut S, Roy-Mayhew JD, Dabbs DM, Milius DL, Aksay IA (2011) High surface area tapes produced with functionalized graphene. ACS Nano 5:5214-5222

88. Liao C, Li Y, Tjong SC (2018) Graphene nanomaterials: synthesis, biocompatibility, and cytotoxicity. Int J Mol Sci 19:3564

89. Sakhnini LI, Pedersen AK, Ahmadian H, Hansen JJ, Bulow L, Dainiak M (2016) Designing monoclonal antibody fragment-based affinity resins with high binding capacity by thiol-directed immobilisation and optimisation of pore/ligand size ratio. J Chromatogr A 1468:143-153

90. Mao S, Lu G, Yu K, Bo Z, Chen J (2010) Specific protein detection using thermally reduced graphene oxide sheet decorated with gold nanoparticle-antibody conjugates. Adv Mater 22:3521-3526

91. Zhang J, Sun Y, Xu B, Zhang H, Gao Y, Zhang H, Song D (2013) A novel surface plasmon resonance biosensor based on graphene oxide decorated with gold nanorod-antibody conjugates for determination of transferrin. Biosens Bioelectron 45:230-236

92. Li H, Wei Q, He J, Li T, Zhao Y, Cai Y, Du B, Qian Z, Yang M (2011) Electrochemical immunosensors for cancer biomarker with signal amplification based on ferrocene functionalized iron oxide nanoparticles. Biosens Bioelectron 26:3590-3595

93. Mao K, Wu D, Li Y, Ma H, Ni Z, Yu H, Luo C, Wei Q, Du B (2012) Labelfree electrochemical immunosensor based on graphene/methylene blue nanocomposite. Anal Biochem 422:22-27

94. Jang HD, Kim SK, Chang H, Choi JW (2015) 3D label-free prostate specific antigen (PSA) immunosensor based on graphene-gold composites. Biosens Bioelectron 63:546-551

95. Xu SJ, Liu Y, Wang TH, Li JH (2011) Positive potential operation of a cathodic electrogenerated chemiluminescence immunosensor based on luminol and graphene for cancer biomarker detection. Anal Chem 83:3817-3823

96. Wu D, Liu Y, Wang Y, Hu L, Ma H, Wang G, Wei Q (2016) Label-free electrochemiluminescent immunosensor for detection of prostate specific antigen based on aminated graphene quantum dots and carboxyl graphene quantum dots. Sci Rep 6:20511

97. Tu J, Gan Y, Liang T, Hu Q, Wang Q, Ren T, Sun Q, Wan H, Wang P (2018) Graphene FET array biosensor based on ssDNA aptamer for ultrasensitive $\mathrm{Hg}(2+)$ detection in environmental pollutants. Front Chem 6:333

98. Ray R, Basu J, Gazi WA, Samanta N, Bhattacharyya K, RoyChaudhuri C (2018) Label-free biomolecule detection in physiological solutions with enhanced sensitivity using graphene nanogrids FET biosensor. IEEE Trans Nanobiosci 17:433-442

99. Sharma B, Kim JS (2018) MEMS based highly sensitive dual FET gas sensor using graphene decorated Pd-Ag alloy nanoparticles for $\mathrm{H} 2$ detection. Sci Rep 8:5902

100. Wang C, Cui X, Li Y, Li H, Huang L, Bi J, Luo J, Ma LQ, Zhou W, Cao Y, Wang B, Miao F (2016) A label-free and portable graphene FET aptasensor for children blood lead detection. Sci Rep 6:21711

101. Basu J, RoyChaudhuri C (2016) Graphene nanogrids FET immunosensor: signal to noise ratio enhancement. Sensors (Basel) 16:1481

102. Mukherjee S, Meshik X, Choi M, Farid S, Datta D, Lan Y, Poduri S, Sarkar K, Baterdene U, Huang CE, Wang YY, Burke P, Dutta M, Stroscio MA (2015) A graphene and aptamer based liquid gated FET-like electrochemical biosensor to detect adenosine triphosphate. IEEE Trans Nanobiosci 14:967-972

103. Farid S, Meshik X, Choi M, Mukherjee S, Lan Y, Parikh D, Poduri S, Baterdene U, Huang CE, Wang YY, Burke P, Dutta M, Stroscio MA (2015) Detection of Interferon gamma using graphene and aptamer based FET-like electrochemical biosensor. Biosens Bioelectron 71:294-299

104. Kakatkar A, Abhilash TS, De Alba R, Parpia JM, Craighead HG (2015) Detection of DNA and poly--Llysine using CVD graphene-channel FET biosensors. Nanotechnology 26:125502

105. Kim DJ, Sohn IY, Jung JH, Yoon OJ, Lee NE, Park JS (2013) Reduced graphene oxide field-effect transistor for label-free femtomolar protein detection. Biosens Bioelectron 41:621-626

106. Wang Q, Ding Y, Gao F, Jiang S, Zhang B, Ni J, Gao F (2013) A sensitive DNA biosensor based on a facile sulfamide coupling reaction for capture probe immobilization. Anal Chim Acta 788:158-164 
107. Ellington AD, Szostak JW (1990) In vitro selection of RNA molecules that bind specific ligands. Nature 346:818-822

108. Robertson DL, Joyce GF (1990) Selection in vitro of an RNA enzyme that specifically cleaves single-stranded DNA. Nature 344:467-468

109. Zhang LQ, Wan S, Jiang Y, Wang YY, Fu T, Liu QL, Cao ZJ, Qiu LP, Tan WH (2017) Molecular elucidation of disease biomarkers at the interface of chemistry and biology. J Am Chem Soc 139(7):2532-2540

110. Zhang J, Li S, Liu F, Zhou L, Shao N, Zhao X (2015) SELEX aptamer used as a probe to detect circulating tumor cells in peripheral blood of pancreatic cancer patients. PLOS ONE 10:e0121920

111. Chen C, Zhou S, Cai Y, Tang F (2017) Nucleic acid aptamer application in diagnosis and therapy of colorectal cancer based on cell-SELEX technology. NPJ Precis Oncol 1:37

112. Sedighian H, Halabian R, Amani J, Heiat M, Amin M, Fooladi AAl (2018) Staggered Target SELEX, a novel approach to isolate non-cross-reactive aptamer for detection of SEA by apta-qPCR. J Biotechnol 286:45-55

113. Kaur H (2018) Recent developments in cell-SELEX technology for aptamer selection. Biochim Biophys Acta Gen Subj 1862:2323-2329

114. Wang X, Li W, Li Z, Li H, Xu D (2015) A highly sensitive fluorescence turn-on platform with silver nanoparticles aptasening for human platelet-derived growth factor-BB. Talanta 144:1273-1278

115. Liu J, Zeng J, Tian Y, Zhou N (2017) An aptamer and functionalized nanoparticle-based strip biosensor for on-site detection of kanamycin in food samples. Analyst 143:182-189

116. Eissa S, Zourob M (2017) Aptamer-based label-free electrochemical biosensor array for the detection of total and glycated hemoglobin in human whole blood. Sci Rep 7:1016

117. Aliakbarinodehi N, Jolly P, Bhalla N, Miodek A, De Micheli G, Estrela P, Carrara S (2017) Aptamer-based field-effect biosensor for tenofovir detection. Sci Rep 7:44409

118. Pan LH, Kuo SH, Lin TY, Lin CW, Fang PY, Yang HW (2017) An electrochemical biosensor to simultaneously detect VEGF and PSA for early prostate cancer diagnosis based on graphene oxide/ssDNA/PLLA nanoparticles. Biosens Bioelectron 89:598-605

119. Settu K, Liu JT, Chen CJ, Tsai JZ (2017) Development of carbongraphene-based aptamer biosensor for EN2 protein detection. Anal Biochem 534:99-107

120. Song Y, Qu K, Zhao C, Ren J, Qu X (2010) Graphene oxide: intrinsic peroxidase catalytic activity and its application to glucose detection. Adv Mater 22:2206-2210

121. Qu FL, Li T, Yang MH (2011) Colorimetric platform for visual detection of cancer biomarker based on intrinsic peroxidase activity of graphene oxide. Biosens Bioelectron 26:3927-3931

122. Hu W, He G, Chen T, Guo CX, Lu Z, Selvaraj JN, Liu Y, Li CM (2014) Graphene oxide-enabled tandem signal amplification for sensitive SPRi immunoassay in serum. Chem Commun 50:2133-2135

123. Li W, Wu P, Zhang H, Cai C (2012) Signal amplification of graphene oxide combining with restriction endonuclease for site-specific determination of DNA methylation and assay of methyltransferase activity. Anal Chem 84:7583-7590
124. Liu M, Chen Q, Lai C, Zhang Y, Deng J, Li H, Yao S (2013) A double signal amplification platform for ultrasensitive and simultaneous detection of ascorbic acid, dopamine, uric acid and acetaminophen based on a nanocomposite of ferrocene thiolate stabilized Fe(3)O(4)@Au nanoparticles with graphene sheet. Biosens Bioelectron 48:75-81

125. Wang B, Akiba U, Anzai Jl (2017) Recent progress in nanomaterial-based electrochemical biosensors for cancer biomarkers: a review. Molecules 22:1048

126. Han J, Zhuo Y, Chai YQ, Yuan R, Zhang W, Zhu Q (2012) Simultaneous electrochemical detection of multiple tumor markers based on dual catalysis amplification of multi-functionalized onion-like mesoporous graphene sheets. Anal Chim Acta 746:70-76

127. Sun $G$, Zhang L, Zhang Y, Yang H, Ma C, Ge S, Yan M, Yu J, Song X (2015) Multiplexed enzyme-free electrochemical immunosensor based on $\mathrm{ZnO}$ nanorods modified reduced graphene oxide-paper electrode and silver deposition-induced signal amplification strategy. Biosens Bioelectron 71:30-36

128. Feng JH, Li YY, Li MD, Li FY, Han J, Dong YH, Chen ZW, Wang P, Liu H, Wei $Q$ (2017) A novel sandwich-type electrochemical immunosensor for PSA detection based on PtCu bimetallic hybrid (2D/2D) rGO/g-C3N4 Biosens Bioelectron 91:441-448

129. Sharafeldin M, Bishop GW, Bhakta S, El-Sawy A, Suib SL, Rusling JF (2017) Fe3O4 nanoparticles on graphene oxide sheets for isolation and ultrasensitive amperometric detection of cancer biomarker proteins. Biosens Bioelectron 91:359-366

130. Zheng Z, Wu L, Li L, Zong S, Wang Z, Cui Y (2018) Simultaneous and highly sensitive detection of multiple breast cancer biomarkers in real samples using a SERS microfluidic chip. Talanta 188:507-515

131. Nie Y, Zhang P, Wang H, Zhuo Y, Chai Y, Yuan R (2017) Ultrasensitive electrochemiluminescence biosensing platform for detection of multiple types of biomarkers toward identical cancer on a single interface. Anal Chem 89:12821-12827

132. Heydari-Bafrooei E, Shamszadeh NS (2017) Electrochemical bioassay development for ultrasensitive aptasensing of prostate specific antigen. Biosens Bioelectron 91:284-292

133. Na W, Liu Q, Sui B, Hu T, Su X (2016) Highly sensitive detection of acid phosphatase by using a graphene quantum dots-based forster resonance energy transfer. Talanta 161:469-475

134. Qu F, Li T, Yang M (2011) Colorimetric platform for visual detection of cancer biomarker based on intrinsic peroxidase activity of graphene oxide. Biosens. Bioelectron 26:3927-3931

\section{Publisher's Note}

Springer Nature remains neutral with regard to jurisdictional claims in published maps and institutional affiliations.

\footnotetext{
Ready to submit your research? Choose BMC and benefit from:

- fast, convenient online submission

- thorough peer review by experienced researchers in your field

- rapid publication on acceptance

- support for research data, including large and complex data types

- gold Open Access which fosters wider collaboration and increased citations

- maximum visibility for your research: over $100 \mathrm{M}$ website views per year
}

At BMC, research is always in progress.

Learn more biomedcentral.com/submissions 